\title{
Faktor-Faktor Yang Mempengaruhi Implementasi Kebijakan Penyelenggaraan Mal Pelayanan Publik
}

\author{
Analysis Of Factors Affecting \\ Policy Implementation Of Public Service Hall
}

\author{
Ratna Puspita Sari* \& Amy Yayuk Sri Rahayu \\ Program Studi Administrasi dan Kebijakan Publik, Fakultas Ilmu Administrasi \\ Universitas Indonesia, Indonesia
}

Diterima:20 Oktober 2020; Disetujui: 17 Desember 2020; Dipublish: 31 Januari 2021

\begin{abstract}
Abstrak
Penelitian ini bertujuan untuk menganalisis faktor - faktor yang mempengaruhi Implementasi Kebijakan Penyelenggaraan Mal Pelayanan Publik di Provinsi DKI Jakarta. Penelitian ini menggunakan model implementasi kebijakan yang dikemukakan oleh Van Meter dan Van Horn (1975) yang terdiri dari beberapa faktor-faktor yaitu (1) Standar dan Tujuan Kebijakan; (2) Sumber Kebijakan; (3) Komunikasi antar Organisasi dan pelaksanaan Kegiatan; (4) Karakteristik Badan Pelaksana; (5) Kondisi Politik, Sosial dan ekonomi; dan (6) kecenderungan pelaksana (implementor). Konsep tersebut digunakan untuk menganalisis faktor-faktor apasaja yang mempengaruhi implementasi kebijakan publik. Penelitian ini menggunakan pendekatan postpositivism dengan metode penelitian kualitatif agar dapat menjelaskan mengenai faktor-faktor apasaja yang mempengaruhi implementasi kebijakan penyelenggaraan Mal Pelayanan Publik (MPP) di Provinsi DKI Jakarta. Teknik pengumpulan data yang digunakan merupakan triangulasi. Secara umum hasil penelitian menggambarkan bahwa penyelenggaraan Mal Pelayanan Publik di Provinsi DKI Jakarta telah berjalan dengan baik, namun ada beberapa faktor seperti sarana dan prasarana yang masih belum memadai, karakteristik badan pelaksana yang belum mendukung pelaksanaan dan komunikasi antar organisasi dan pelaksanaan kegiatan belum terjalin dengan konsisten, sehingga berdampak pada pemberian layanan ke masyarakat.

Kata Kunci: Implementasi Kebijakan, Mal Pelayanan Publik
\end{abstract}

\begin{abstract}
This study aims to analyze the factors that influence the Implementation of Public Service Mall Implementation Policies in DKI Jakarta Province. This study uses a policy implementation model proposed by Van Meter and Van Horn (1975) which consists of several factors, namely (1) Policy Standards and Objectives; (2) Policy Sources; (3) Communication between organizations and implementation of Activities; (4) Characteristics of the Implementing Body; (5) Sociopolitical and economic conditions; and (6) the trend of implementers (implementors). This concept is used to analyze the factors that influence the implementation of public policies. This study uses a post-positivist approach with qualitative research methods in order to explain the factors that influence the implementation of policies on the implementation of public service malls in DKI Jakarta Province. The data collection technique used was triangulation. In general, the research results illustrate that the implementation of Public Service Hall in DKI Jakarta Province has been going well, but there are several factors such as inadequate facilities and infrastructure, characteristics of implementing agencies that have not supported the implementation and communication between organizations and the implementation of activities has not been consistent, thus having an impact on service delivery to the community. Keywords: Policy Implementation, Public Service Hall
\end{abstract}

How to Cite: Sari, R.P \& Rahayu, A.Y.S (2021). Faktor-Faktor Yang Mempengaruhi Implementasi Kebijakan Penyelenggaraan Mal Pelayanan Publik Di Provinsi DKI Jakarta.PERSPEKTIF, 10(1): 230-238

*Corresponding author:

E-mail: ratnapuspita@gmail.com

ISSN 2085-0328 (Print) ISSN 2684-9305(Online) 


\section{PENDAHULUAN}

Undang-Undang Nomor 25 Tahun 2009 mendefinisikan pelayanan publik sebagai kegiatan pemenuhan kebutuhan pelayanan sesuai atas jasa, barang ataupun pelayanan administratif yang disediakan oleh penyelenggara layanan publik. Untuk itu kebijakan yang matang diperlukan agar memberikan dampak positif bagi masyarakat dalam mengakses layanan publik. (Dye, 1878) memaknai kebijakan sebagai "whatever government choose to do or not to do. What government do why they do it, and what difference it makes". Upaya peningkatan layanan publik yang berkualitas di sektor perizinan terus realisasikan karena memiliki pengaruh langsung pada sektor ekonomi, Salah satu upaya pemerintah dalam memperbaiki layanan publik pada sektor perizinan yaitu salahsatunya menerbitkan Perpres No. 97 Tahun 2014 Tentang Penyelenggaraan PTSP yang kemudian disusul oleh Permendagri No. 138 Tahun 2017 Tentang Penyelenggaraan PTSP Daerah. Mengingat adanya UU Nomor 23 Tahun 2014 Tentang Pemerintahan Daerah maka harapannya pembentukan PTSP di Daerah agar lebih mendekatkan pelayanan pemerintah dengan masyarakat.

Namun penyelenggaraan PTSP pada Pemerintah Daerah ini bukan tanpa kendala, Penyelenggaraan PTSP yang melekat pada DPMPTSP Provinsi dan Kabupaten/Kota pada tahap Implementasinya masih memiliki kendala yaitu (1) permasalahan pelimpahan kewenangan perizinan dimana masih tingginya ketidakpatuhan pada pelaksanaan PTSP dan belum terwujudnya efektivitas dan percepatan pelayanan perizinan; (2) Adanya pelaksanaan Online Single Submission yang masih terkendala oleh produk pelayanan yang tidak seragam di tiap daerah, lambanya penyesuaian Standar Operasional Prosedur (SOP) serta sistem teknologi yang belum terintegrasi (Ombudsman RI, 2019).

Kendala tersebut terjadi karena selama satu dekade terakhir ini manajemen bidang pemerintahan di Indonesia sedang mengalami fragmentasi berlebihan, dampak dari birokrasi Webrian ternyata mendorong adanya spesialisasi dan diferensiasi membuat struktur birokrasi pemerintahan terfragmentasi secara spasial dan sectoral berada pasa suatu lingkup sempit sehingga urusan pemerintah menjadi semakin rumit (Dwiyanto, 2014). Apabila pendistribusian kewenangan untuk mengelola suatu kegiatan pemerintahan diberikan ke banyak organisasi/instansi baik pusat maupun daerah tentunya membutuhkan koordinasi dan kesamaan persepsi yang baik. Apabila kondisi koordinasi antar instansi tidak terjalin dengan baik, maka akan berdampak pada sulitnya pemerintah dalam mengekseskusi kebijakankebijakan publiknya. Fragmentasi inilah yang memiliki kecenderungan dan menjadi penyebab munculnya ego sectoral/silomentality pada lingkungan birokrasi maupun dikalangan Aparatur Sipil Negara (ASN). Dengan fragmentasi dan ego sektoral dapat berdampak pada sulitnya mengembangkan Whole Of Government dalam birokrasi Indonesia.

Belum selesai dengan kendala dari adanya kebijakan penyelenggaraa PTSP di Daerah, kini Kementerian PAN RB mengagas PERMENPANRB Nomor 23 Tahun 2017 Tentang Penyelenggaraan Mal Pelayanan Publik yang memiliki tujuan untuk memberikan kecepatan, kemudahan, kenyamanan, keterjangkauan, serta keamanan untuk warga masyarakat dalam mengakses pelayanan publik, serta adanya maksud untuk meningkatkan kegiatan perekonomian yang mampu meningkatkan daya saing global yang juga berdampak pada mempermudah untuk memulai kegiatan berusaha di Indonesia. MPP ini dimaksudkan sebagai perluasan fungsi dari PTSP yang sama-sama menggunakan konsep One Stop Service, yang diharapkan mampu meningkatkan jumlah investasi dan kemudahan menjalankan usaha di Indonesia, namun masih memerlukan perbaikan regulasi, koordinasi, peningkatan SDM dan peggunaan teknologi agar implementasinya menjadi lebih baik (El Anshori, Enceng, \& Harta, 2017).

Berdasarkan PERMENPAN RB No. 23 Tahun 2017 Tentang Penyelenggaraan Mal Pelayanan Publik(MPP), pelaksanaan MPP dapat dilakukan oleh organisasi pada perangkat daerah yang memiliki fungsi dan tugas pada bidang penanaman modal dan PTSP, dimana organisasi tersebut memiliki tugas dan fungsi untuk mengikutsertakan pelayanan Kementerian/Lembaga/Pemerintah Daerah lainnya, serta pelayanan BUMN/BUMD/Swasta. Sehubungan dengan upaya yang telah diupayakan Pemerintah Pusat dan Pemerintahan Daerah untuk menyelenggarakan MPP terdapat 
permasalahan yang menyebabkan tidak optimalnya MPP yaitu dari perspektif kebijakan publik dapat dilihat pada kebijakan-kebijakan yang mendasarinya maupun pada tahap kebijakan tersebut diimplementasikan. Implementasi kebijakan merupakan tahap pelaksanaan dari alternatif suatu kebijakan yang diputuskan oleh badan-badan administratif (Dunn, 1999). Implementasi MPP di Daerah memiliki berbagai kendala, salah satunya Sidak Ombudsman RI ke MPP Kota Padang yang dinilai belum memenuhi kualifikasi standar pelayanan sesuai dengan amanat UU Nomor 25 Tahun 2009 Tentang Pelayanan Publik, belum adanya kepastian penyelenggaraan layanan dan masih adanya faktor indisipliner pegawai (ombudsman.go.id).

Tahap implementasi kebijakan memegang peranan penting dalam suatu kebijakan publik, namun proses implementasi kebijakan yang sangat kompleks akan membuat suatu kebijakan dapat berbeda dengan kebijakan lain (Edward III, 1980) sedangkan (Grindle, 1980) memahami implementasi sebagai proses administrasi dan politik, keberhasilan suatu implementasi kebijakan dipengaruhi oleh dua variabel yaitu lingkungan implementasi (context of implementation) dan isi kebijakan (content of policy). Implementasi Kebijakan Penyelenggaraan Mal Pelayanan tentu membutuhkan dukungan dari banyak pihak baik daerah maupun pusat serta lembagalembaga yang akan tergabung. komitmen dari pemangku jabatan dan konsistensi diperlukan dalam penyelenggaraannya. Singkronisasi dan harmonisasi aturan-aturan yang ada diperlukan agar pelaksanaannya berjalan dengan optimal. masih ditemukannya kendala penyelenggaraan pelayanan terpadu baik di daerah maupun di pusat belum mampu berjalan dengan baik, minimnya penggunaan teknologi informasi terkait layanan perizinan dan menguatnya ego sektoral / silomentality (bahan paparan deputi pelayanan publik KemenPAN RB, 2018) hal ini juga sebagai upaya penyelenggaraan pelayanan publik dengan konsep one stop service dalam menjalankan pengadministrasian penyelenggaraan pelayanan publik yang duharapkan mampu mengatasi permasalahan birokrasi saat ini (Suryanegara, 2019).
Provinsi DKI Jakarta menjadi pilot project berdasarkan Keputusan Menteri PAN dan RB No. 135 Tahun 2017 Tentang Penetapan Percontohan Mal Pelayanan Publik, menetapkan Mal Pelayanan Publik Pemprov DKI Jakarta, Mal Pelayanan Publik Kota Surabaya, Mal Pelayanan Publik Kota Batam dan Mal Pelayanan Publik Kota Denpasar sebagai percontohan. Penyelenggaraan Mal Pelayanan Publik Provinsi DKI Jakarta mulai menerima pelayanan pada tanggal 12 Oktober tahun 2017 dan diresmikan langsung oleh Menteri Pendayagunaan Aparatur Negara dan Reformasi Birokrasi. Jumlah pelayanan yang diberikan sejumlah 327 jenis pelayanan sejumlah 269 pelayanan Pemprov DKI Jakarta dan 58 perizinan dari 13 Kementerian/Lembaga/BUMN/BUMD. Sesuai dengan Pergub Provinsi DKI Jakarta Nomor 142 Tahun 2017 Tentang Mal Pelayanan Publik dimana Dinas Penanaman Modal dan Pelayanan Terpadu Satu Pintu (DPMPTSP) merupakan instansi yang melakukan pengendalian manajemen serta mengelola operasional penyelenggaraan Mal Pelayanan Publik, serta memiliki kewenangan dalam menyusun tata tertib dan membuat laporan yang memuat analisa terhadap pelaksanaan tata tertib tersebut.

Implementasi kebijakan dimaknai sebagai upaya/tindakan yang dilakukan oleh lembaga pemerintah dalam mencapai apasaja tujuan-tujuan yang sebelumnya telah ditetapkan (Van Meter \& Van Horn, 1975). Artinya implementasi kebijakan merupakan proses penting dalam ilmu kebijakan publik, dimana tujuan kebijakan dapat dicapai atau tidak. Berkaitan dengan penyelenggaraan MPP di Provinsi DKI Jakarta, terdapat beberapa kendala-kendala yang dikemukakan pada tahap implementasinya, yaitu belum adanya kebijakan yang secara teknis menetapkan pembagian tugas yang jelas dan masih kurangnya jalinan komunikasi yang baik serta koordinasi yang panjang pada tatanan birokrasi karena penyelenggaraan MPP membutuhkan koordinasi baik horizontal dan vertikal sehingga memerlukan dukungan penuh dari banyak pihak baik itu dari Kementerian/Lembaga, BUMN, BUMD maupun swasta yang terlibat juga dengan Kementerian PAN RB sebagai trigger pada penyelenggaraan MPP, sehingga masih terlihat adanya distorsi dan gap antara tujuan kebijakan dengan 
pelaksanaannya yang tidak sesuai. Belum optimalnya koordinasi dan komitmen juga dapat berdampak pada pelayanan yang diberikan. terdapat beberapa pengaduan dari masyarakat yang belum memahami prosedur pendaftaran antrian online seperti layanan yang diberikan oleh DPMPTSP dan layanan imigrasi (megapolitan.kompas.com), serta Hasil survey Ease of Doing Business (EODB) yang dilakukan oleh Bank Dunia pada tahun 2018 berhasil naik di posisi peringkat 72 namun pada tahun 2019 menurun 1 peringkat berada di posisi 73 dimana Provinsi DKI Jakarta berkontribusi sebesar $78 \%$ pada penilaian kemudahan berusaha. Berkaitan dengan permasalahan tersebut, penelitian ini bermaksud untuk menganalisis faktor-faktor apa saja yang mempengaruhi penyelenggaraan Mal Pelayanan Publik di Provinsi DKI Jakarta pada tahap implementasinya.

\section{METODE PENELITIAN}

Pendekatan yang digunakan pada penelitian ini yaitu pendekatan postpositivism karena peneliti menurunkan konsep implementasi kebijakan, variabel serta indikator dengan konsep (Van Meter \& Van Horn, 1975). Penelitian ini berupaya menggaali apa yang menjadi permasalahan dalam implementasi kebijakan dalam penyelenggaraan MPP di Provinsi DKI Jakarta. Dengan demikian peneltian ini menggunakan alur pemikiran deduktif - induktif dan dimulai dari menurunkan hasil temuan awal penelitian dengan konsep yang relevan untuk digunakan.

Berdasarkan tujuannya menggunakan pendekatan kualitatif dimana menurut Taylor dan Bogdan dalam (Moleong, 2010) metode kualitatif digunakan sebagai prosedur penelitian yang menghasilkan data yang berssifat deskriptif berupa lisan maupun katakata tertulis dari orang terhadap perilaku yang diamati. Tulisan ini juga menggunakan studi kepustakaan sehingga data-data yang dihasilkan dapat diperoleh dari data sekunder melalui studi literatur dari beberapa referensi jurnal, buku maupun artikel yang berhubungan dengan tema serta data-sata sekunder yang didapat dari Pemerintah Provinsi DKI Jakarta.

Secara garis besar, penelitian ini mencakup pokok bahasan yang merupakan deskripsi mengenai hasil analisis pada faktorfaktor apasaja yang mempengaruhi implementasi suatu kebijakan. kajian pertama berupaya mengidentifikasikan suatu kebijakan yang diimplementasikan yang berbentuk suatu peraturan dapat mencapai tujuan atau sasaran yang dikehendaki oleh pembuat kebijakan. Penelitian ini menggunakan konsep implementasi kebijakan dari (Van Meter \& Van Horn, 1975) mengemukakan 6 (enam) variabel yang mempengaruhi keberhasilan implementasi kebijakan yaitu (1) standar dan tujuan kebijakan; (2) sumber daya kebijakan; (3) karakteristik badan-badan pelaksana; (4) komunikasi antar organisasi dengan kegiatan pelaksanaan; (5) sikap/disposisi pelaksana/ implementor; dan (6) kondisi sosial, politik dan ekonomi. Sedangkan kajian kedua membahas mengenai faktor-faktor yang mempengaruhi saat kebijakan diimplementasikan dengan realisasi di lapangan agar dapat memberikan saran untuk mengatasi kesenjangan (gap) yang terjadi.

Lokus penelitian pada tulisan ini yaitu pada Penyelenggaraan Mal Pelayanan Publik (MPP) di Provinsi DKI Jakarta karena menjadi salah satu pilot project penyelenggaraan Mal Pelayanan Publik dimana penyelenggaraan pelayanan publik di Provinsi DKI Jakarta berkontribusi sebesar $78 \%$ dalam penilaian kemudahan berusaha yang dilakukan oleh Bank Dunia.

Lebih fokus lagi penelitian ini dilakukan di Dinas Penanaman Modal dan Pelayanan Terpadu Satu Pintu Provinsi DKI Jakarta, dimana dalam Peraturan Gubernur Nomor 142 Tahun 2017 Tentang Mal Pelayanan Publik DPMPTSP adalah organisasi perangkat daerah yang melaksanakan pengelolaan operasional Mal Pelayanan Publik

Menurut Bungin (2013) Metode pengumpulan data pada penelitian kualitatif adalah melalui wawancara mendalam dan observasi partisipasi. Teknik pengumpulan data yang pantas digunakan pada penelitian yang menggunakan pendekatan kualitatif (postpositivism) yaitu wawancara mendalam, observasi dan studi dokumentasi (Indrawan \& Yaniati, 2016).

Peneliti menggunakan metode wawancara mendalam dengan pemangku kepentingan yang terkait dengan kebijakan implementasi kebijakan mal pelayanan publik, untuk menganalisis jawaban sesuai dengan operasionalisasi konsep yang telah ditetapkan. Peneliti juga menggunakan data sekunder yang dapat digali melalui studi literatur sebagai 
acuan guna membandingkan data hasil wawancara dengan model implementasi kebijakan Van Meter dan Van Horn.

Sumber data merupakan komponen yang paling penting dalam suatu penelitian. Penulis harus memilih sumber data yang relevan dan mampu menjawab pertanyaan penelitian. Terdapat dua jenis sumber data yang digunakan pada penelitian ini, yaitu sumber data primer dan sumber data sekunder, yaitu : (a) Sumber data primer merupakan sumber informasi pertama dimana sebuah data dihasilkan. Sumber data primer dapat didapatkan melalui wawancara dari responden yang sudah ditetapkan; (b) Sumber data sekunder merupakan informasi yang dihasilkan dari sumber data kedua/sekunder. Sumber data ini dapat digunakan sebagai data pelengkap maupun sebagai materi pembanding (Bungin, 2013)

Agar dapat memenuhi sumber data, baik sumber data primer maupun sumber data sekunder, peneliti akan melakukan wawancara mendalam dengan para pejabat di lingkungan DPMPTSP Provinsi DKI Jakarta dan beberapa instansi terkait yang tergabung pada penyelenggaraan MPP di Provinsi DKI Jakarta. Pemilihan informan akan dilakukan dengan prosedur purposive yang dianggap mewakili dan menguasai permasalahan yang akan diteliti dan prosedur bola salju (snowball) (Bungin B. , 2007) yaitu menggunakan metode informan kunci yang berkontribusi memberikan informasi kepada peneliti.

\section{HASIL DAN PEMBAHASAN}

Implementasi

kebijakan

penyelenggaraan Mal Pelayanan Publik (MPP) di Provinsi DKI Jakarta tentunya harus sesuai dengan harapan dan ekpektasi masyarakat terhadap penyelenggaraan pelayanan publik. Mengingat Jakarta dengan statusnya sebagai Ibukota Negara tentunya dijadikan sebagai role model bagi pemerintah daerah lainnya dalam penyelenggaraan program-program strategis. pengorganisasian dan pengelolaan penyelenggaraan Mal Pelayanan Publik dilakukan secara berjenjang dan melalui mekanisme koordinasi. dalam penyelenggaraan Mal Pelayanan Publik koordinasi dilakukan oleh DPMPTSP Provinsi DKI Jakarta dengan Tim Koordinasi Kerja Sama Daerah yang memiliki tugas diantaranya : (a) menyusun prioritas objek yang akan dikerjasamakan; (b) melakukan inventarisasi dan pemetaan bidang/potensi daerah yang akan dikerjasamakan; (c) menyiapkan kerangka acual/proposal objek kerja sama daerah; (d) memberikan saran terhadap proses pemilihan daerah dan pihak ketiga; (e) menyiapkan materi kesepakatan bersama dan rancangan perjanjian kerja sama; (f) membuat dan menilai proposal dan studi kelayakan; (g) melakukan pembinaan dan pengawasan terhadap pelaksanaan kerja sama daerah Kabupaten/Kota; dan (h) memberikan rekomendasi kepada Gubernur untuk penandatanganan kesepakatan bersama dan perjanjian kerja sama.

Tabel 1. Penyelenggaraan Layanan di Mal Pelayanan Publik Provinsi DKI Jakarta

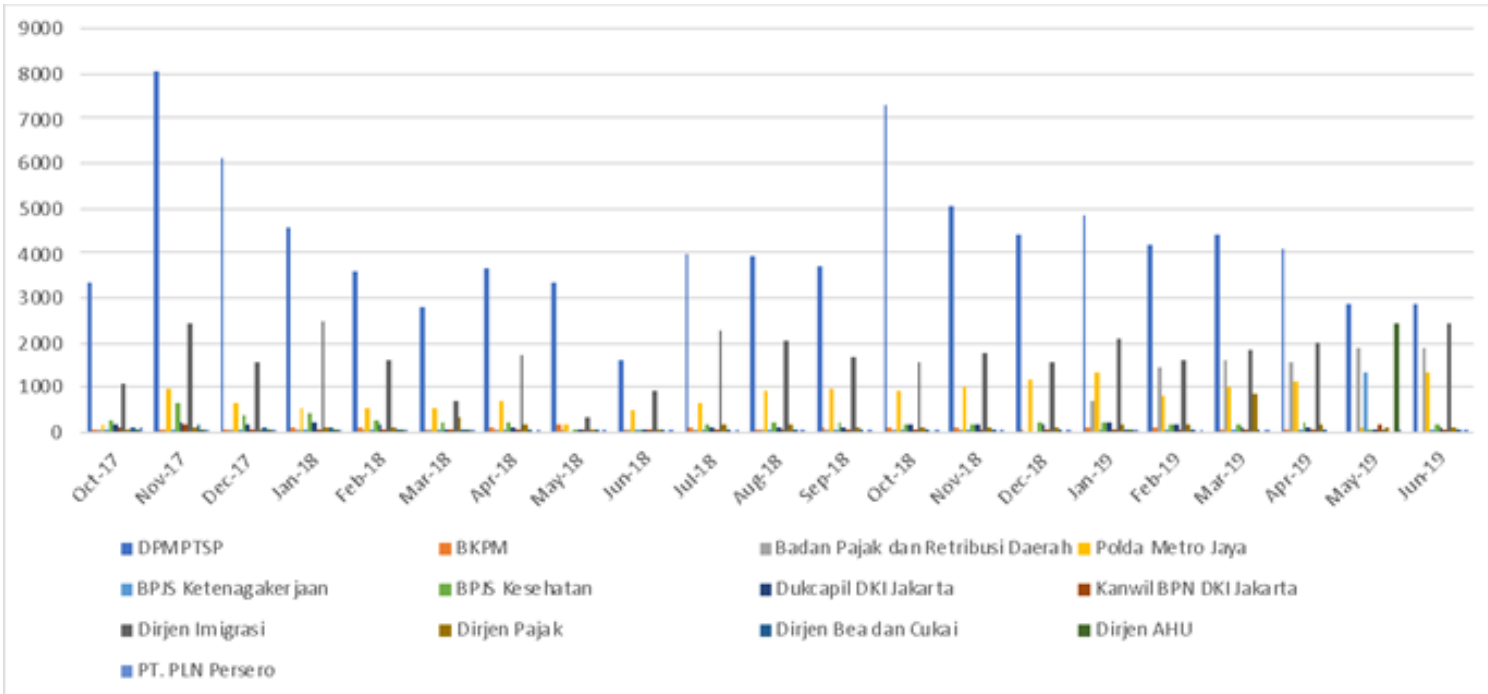

Sumber : DPMPTSP Provinsi DKI Jakarta 
Rata-rata jumlah pelayanan yang diberikan di MPP DKI mencapai 621 layanan perbulannya dari seluruh instansi Selama selama kurun waktu pelaksanaannya selama 24 bulan. Layanan yang paling banyak dicari masih didominasi oleh DPMPTSP dengan rata-rata permohonan sebesar 4200 per bulan. Berdasarkan tabel tersebut layanan yang diberikan oleh DPMPTSP, Kantor Imigrasi dan pelayanan Polda Metro Jaya dimanfaatkan masyarakat secara maksimal. tentunya hal tersebut dipengaruhi oleh kemudahan masyarakat mengakses instansi tersebut.

Untuk mengimplementasikan penyelenggaraan Mal Pelayanan Publik, Pada dasarnya proses memerlukan komitmen dan kerja sama yang baik agar tujuan dapat tercapai. Ada beberapa faktor-faktor yang mempengaruhi proses implementasi kebijakan yang dikemukakan oleh (Van Meter \& Van Horn, 1975), yaitu (1) Standar dan Tujuan Kebijakan; (2) Sumber Kebijakan;

Komunikasi antar Organisasi dan pelaksanaan Kegiatan; (4) Karakteristik Badan Pelaksana; (5) Kondisi Sosial Politik dan ekonomi; dan (6) kecenderungan pelaksana (implementor)

\section{Standar dan Tujuan Kebijakan}

Standar dan tujuan yang harus dicapai oleh pelaksana kebijakan sesuai dengan apa yang telah ditetapkan sebelumnya. maka kinerja kebijakan dapat diukur dari ketercapaian standar dan tujuan tersebut. Namun, Implementasi Kebijakan bisa jadi gagal apabila pelaksana tidak sepenuhna mengetahui standar dan tujuan yang ingin dicapai dari suatu kebijakan. Secara umum tujuan dari penyelenggaraan Mal Pelayanan Publik sesuai Peraturan Gubernur Nomor 142, yaitu : (a) menyederhanakan persyaratan, prosedur dan sistem; (b) mengintegrasikan berbagai layanan baik instansi Pusat dan Daerah dalam satu lokasi atau gedung yang sama; (c) memberikan kemudahan kepada pengguna layanan dalam memproses layanan pada satu lokasi atau gedung; (d) meningkatkan komitmen, kerja sama dan sinergi para penyelenggara layanan dalam ranga penyediaan, pemanfaatan dan pengembangan layanan publik; (e) meningkatkan kualitas pelayanan perizinan dengan pelayanan yang lebih cepat, mudah, terjangkau, transparan dan akuntabel serta bebas dari pungutan liar; dan (f) mendorong peningkatan investasi dan pertumbuhan ekonomi.

Untuk mencapai tujuan dibutuhkan peran Dinas Penanaman Modal dan Pelayanan Terpadu Satu Pintu (DPMPTSP) Provinsi DKI Jakarta merupakan pengendali dan pengelola operasional Mal Pelayanan Publik dan peran dari Tim Koordinasi Kerja Sama Daerah dalam mekanisme perjanjian kerja sama antara Kepala Daerah dengan Kementerian/Lembaga/BUMN/BUMD maupun swasta yang bergabung dengan pengelenggaraan Mal Pelayanan Publik. Agar penyelenggaraan Mal Pelayanan Pulik di Provinsi DKI Jakarta dapat berjalan dengan Baik maka Pemerintah Daerah berkoordinasi dengan Kementerian/Lembaga/BUMN/BUMD maupun swasta yang akan bergabung dalam penyelenggaraan Mal Pelayanan Publik. Pemilihan jenis layanan berdasarkan indikatorindikator yang menjadi penilaian Ease Of Doing Bussines (EODB).

Dari hasil penelitian disimpulkan bahwa Penyelenggaraan Mal Pelayanan Publik di Provinsi DKI Jakarta ini memiliki sasaran yang cukup jelas namun standar ataupun tujuan serta sosialisasi masih kurang dilaksanakan dengan baik yang dapat mengakibatkan para pelaksana belum dapat sepenuhnya memenuhi standar karena kelemahan dalam hal kejelasan tujuan dan sosialisasi sehingga proses integrasi belum sepenuhnya berjalan dengan baik.

\section{Sumber Daya}

Menurut Van Meter dan Van Horn, Sumberdaya juga merupakan faktor penting karena sumber daya dapat digunakan untuk memfasilitasi pelaksanaan program. kemampuan memanfaatkan sumber daya yang tersedia dapat mempengaruhi keberhasilan implementasi kebijakan dan setiap implementasi kebijakan membutuhkan sumber daya yang sesuai dengan kemampuannya. selain sumber daya manusia, waktu dan sumber pendanaan juga merupakan faktor penting atas keberhasilan proses implementasi kebijakan.

Sumber Daya Manusia, Pada pasal 5 Peraturan Gubernur Nomor 142 Tentang Mal Pelayanan Publik jelas menyebutkan bahwa 
sumber daya manusia dalam penyelenggaraan Mal Pelayanan Publik terdiri dari masingmasing Kementerian/Lembaga/Perangkat Daerah/Lembaga Berbadan Hukum. Pada pelanksanaanya SDM memang diatur oleh masing-masing lembaga yang tergabung pada penyelenggaraan Mal Pelayanan Publik di Provinsi DKI Jakarta, namun hal ini ternyata menjadi kendala tersendiri karena tidak dapat mengelola dan mengontrol SDM secara terpusat sehingga pada pelaksanaannya terjadi ketidakseragaman pemberian layanan.

Sumber Pendanaan, Terkait pembiayaan Pasal 10 Ayat (1) Pergub 142 Tahun 2017 Tentang Penyelenggaraan Mal Pelayanan Publik bahwa biaya pelaksanaan Mal Pelayanan Publik dapat dibebankan pada Anggaran Pendapatan dan Belanja Daerah (APBD) melalui dokumen pelaksanaan Anggaran (DPA). Sedangkan pada Ayat (2) dijelaskan bahwa anggaran biaya pelaksana sebagaimana dimaksud pada ayat (1) terdiri dari: a. Pengelolaan Gedung; (b) penyediaan sarana dan prasarana standar sesuai standarisasi peralatan kerja; dan (c) Penyediaan telepon, air, listrik dan internet. Pada Ayat (3) Anggaran biaya dari sumber lain yang sah sebagaimana dimaksud pada ayat (1) diatur dalam perjanjian Kerja Sama; sedangkan pada Ayat (4) disebutkan bahwa anggaran selain yang disebutkan pada ayat (1) dibebankan pada masing-masing penyelenggara layanan.

Sarana dan Prasarana, Berdasarkan Keputusan Gubernur Provinsi DKI Jakarta Nomor 1856 Tahun 2017 Tentang Gedung Mal Pelayanan Publik, menetapkan nama dan peruntukan Gedung Teknis yang berlokasi di Jalan HR. Rasuna Said Kav. C.22, Kelurahan Karet Kuningan, Kecamatan Setiabudi, Kota Administrasi Jakarta Selatan sebagai Gedung Mal Pelayanan Publik. Namun, ada beberapa catatan dari Polda Metro Jaya yang menyatakan kalau lokasi MPP itu kurang strategis sehingga kunjungan masyarakat ke MPP dirasa kurang maksimal. beberapa instansi yang tergabung pada penyelenggaraan MPP juga masih belum dapat memberikan pelayanan yang maksimal karena keterbatasan infrastruktur yang disediakan di MPP.

\section{Karakteristik Badan-badan Pelaksana} Pembahasan mengenai faktor karakteristik badan pelaksana dapat mempengaruhi proses implementasi kebijakan dimaknai oleh Van Meter dan Van Horn yang menitikberatkan pada dinamika struktur birokrasi. Komponen dari variabel ini menjelaskan beberapa unsur yang dapat mempengaruhi proses implementasi kebijakan pada suatu organisasi. Pada penyelenggaraan MPP di Provinsi DKI Jakarta dimana sesuai Perajanjian Kerja Sama dilakukan antara Pemerintah Provinsi DKI Jakarta dengan 10 Kementerian/Lembaga/Instansi/BUMN/BUM D maupun swasta ini berdasarkan hasil wawancara dengan Tim Koordinasi Kerja Sama Daerah Provinsi DKI Jakarta ini mendapatkan dorongan dari KemenPANRB berdasarkan PerMenPAN RB Nomor 23 Tahun 2017 Tentang Penyelenggaraan Mal Pelayanan Publik dimana Pemerintah Provinsi DKI Jakarta menjadi Pilot Project penyelenggaraan Mal Pelayanan Publik di daerah. Sehingga pada awalnya teknis penyelenggaraan untuk mengintergasikan layanan dari berbagai instansi dapat sedikit lebih mudah karena adanya dorongan dari pusat tersebut. Namun pada pelaksanaanya kebijakan penyelenggaraan Mal Pelayanan Publik di Provinsi DKI Jakarta ini sangat membutuhkan komitmen dari instansi penyelenggara agar berjalan sesuai dengan rencana semula. Mengingat kebijakan ini memerlukan komitmen para pelaksana agar berjalan sesuai dengan tujuan yang telah ditetapkan.

Pada penyelenggaraan MPP Standar Operational Prosedur (SOP) makro yang berkaitan dengan mekanisme pelayanannya belum tersedia. Sehingga pembagian tugas dan mekanisme pelayanan yang diberikan oleh Kementerian/Lembaga/BUMN/BUMD maupun swasta yang bergabung dalam MPP DKI belum megatur mengenai mekanisme waktu operasional layanan. SOP yang telah disusun namun sebatas untuk mengatur mekanisme internal pada masing - masing instansi. Mekanisme yang tidak seragam ini dapat menimbulkan ketidakpastian masyarakat dalam mendapatkan pelayanan.

\section{Komunikasi Antar Organisasi dan \\ Pelaksanaan Kegiatan}

Menurut Van Meter Van Horn komunikasi antar badan-badan pelaksana dalam proses implementasi kebijakan dapat dipengaruhi oleh standar dan tujuan kebijakan dengan kata lain komunikasi akan berjalan efektif apabila standar dan tujuan kebijakan dimengerti oleh 
individu-individu yang memiliki tanggung jawab pada kinerja kebijakan. Pada penyelenggaraan Mal Pelayanan Publik di Provinsi DKI Jakarta, komunikasi antara Pemerintah Provinsi DKI Jakarta dengan Kementerian/Lembaga yang bergabung dengan penyelenggaraan MPP selain membutuhkan komunikasi formal, juga membutuhkan komunikasi informal dimana ukuran-ukuran dasar dan tujuan kebijakan penyelenggaraan Mal Pelayanan Publik merupakan suatu upaya dalam mengintegrasikan penyelenggaraan pelayanan publik yang secara hirarkis dipengaruhi oleh komunikasi seorang pimpinan dalam suatu organisasi dalam menyampaikan standar dan tujuan kebijakan kepada pelaksana kebijakan. Pada faktor ini, mekanisme kelembagaan dapat mempengaruhi keberhasilan proses komunikasi. Penyelenggaraan Mal Pelayanan Publik yang melibatkan berbagai institusi masih merupakan hal yang kompleks, berdasarkan hasil wawancara dan observasi proses koordinasi masih mengalami kendala dimana masih terdapat beberapa Institusi yang tidak menghadiri rapat koordinasi dan masih kurangnya intensitas penyelenggaraan Rapat koordinasi pada institusi yang bergabung.

Berkaitan dengan permasalahan koordinasi narasumber menyadari bahwa masih adanya permasalahan koordinasi yang perlu diperbaiki. intensitas koordinasi baik vertical maupun komunikasi horizontal yang belum sesuai dengan harapan. Tentunya Penyelenggaraan MPP ini membutuhkan komitmen yang kuat untuk saling bersinergi antara Pusat dan Daerah maupun swasta dalam memberikan pelayanan publik yang baik.

\section{Kondisi Sosial, Politik dan Ekonomi}

Van Meter Van Horn dalam (Winarno, 2012) menyatakan bahwa lingkungan ekonomi, politik dan sosial dari organisasi pelaksana, dapat mempengaruhi karakter dari badanbadan pelaksana, kecenderungan para pelaksana pada tahap implementasi. Dalam penyelenggaraan Mal Pelayanan Publik di Provinsi DKI Jakarta, menurut hasil wawancara dengan narasumber sangat memiliki pengaruh yang kuat. Dukungan dari KemenPAN RB sangat mendukung penuh provinsi DKI Jakarta menjadi role model pembangunan MPP di daerah. Dengan adanya Keputusan Menteri PAN dan RB No. 135 Tahun 2017 Tentang
Penetapan Percontohan Mal Pelayanan Publik, yaitu Pemprov DKI Jakarta, Mal Pelayanan Publik Kota Surabaya, Mal Pelayanan Publik Kota Batam dan Mal Pelayanan Publik Kota Denpasar. Dukungan ini tidak terlepas upaya memenuhi target Pemerintah Pusat dalam meningkatkan peringkat Ease of Doing Bussiness (EODB) Indonesia ke peringkat 40 Besar. Dimana Provinsi DKI Jakarta berkontribusi 78\% dalam penilaian EODB yang setiap tahunnya diselenggarakan oleh Bank Dunia.

\section{Kecenderungan Pelaksana (Implementor)}

Van Meter dan Van Horn menjelaskan 3 (tiga) faktor yang dapat mempengaruhi pelaksana untuk melaksanakan atau tidak melaksanakan suatu kebijakan, yaitu : (1) yaitu pemahaman pelaksana terhadap suatu kebijakan; (2) berbagai tanggapan/respon terhadap suatu kebijakan, seperti memberikan respon menerima, netral atau menolak suatu kebijakan; dan (3) frekuensi tanggapan terhadap hal tersebut. penyelenggaraan Mal Pelayanan Publik di Provinsi DKI Jakarta dapat dipengaruhi oleh kecenderungan pelaksana. Standar dan tujuan yang belum dipahami sepenuhnya mempengaruhi proses implementasi kebijakan penyelenggaraan Mal Pelayanan Publik menjadi kurang optimal. Hal ini dibuktikan dari kurangnya intensitas rapat koordinasi dengan instansi-instansi yang tergabung beserta kurangnya monitoring pelaksanaan Mal Pelayanan Publik, sehingga penyelenggaraan layanan publik masih mendapatkan respon yang kurang baik dari masyarakat.

MPP merupakan Kebijakan yang pada tahap implementasinya membutuhkan koordinasi lintas sektoral, bertujuan untuk memberikan pelayanan publik yang baik untuk masyarakat. Penyelenggaraan MPP DKI Jakarta melibatkan Kementerian PAN dan RB dan berkoordinasi dengan Kementerian/ Lembaga yang akan bergabung dengan penyelenggaraan MPP tentunya memiliki keterkaitan untuk pembahasan mekanisme pelayanan yang akan dilaksanakan sampai dengan penyediaan SDM.

\section{SIMPULAN}

Implementasi

kebijakan penyelenggaraan Mal Pelayanan Publik di Provinsi DKI Jakarta merupakan amanat dari Peraturan Menteri Pendayagunaan Aparatur 
Negara dan Reformasi Birokrasi Nomor 23 Tahun 2017 Tentang Penyelenggaraan Mal Pelayanan Publik. Jakarta juga merupakan pilot project dari adanya penyelenggaraan Mal Pelayanan Publik berdasarkan Keputusan MenPAN RB Nomor 135 Tahun 2017 tentang Penetapan Percontohan Mal Pelayanan Publik. Faktor-faktor yang mempengaruhi Implementasi Kebijakan Penyelenggaraan Mal Pelayanan Publik yang telah dianalisis dengan Model Van Meter dan Van Horn secara umum dapat terlaksana dengan baik, namun standar dan tujuan yang masih belum dijelaskan lebih spesifik dapat menimbulkan kebebasan interpretasi pelaksana kebijakan sehingga integrasi pelayanan yang diberikan belum berjalan optimal. faktor lain yang memiliki kendala dalam pelaksanaannya yaitu berkaitan dengan keterbatasan sarana dan prasarana penunjang, struktur birokrasi yang belum mendukung pengembangan pola layanan terintegrasi, serta kurangnya koordinasi antar pelaksana yang menyebabkan penyelenggaraan Mal Pelayanan Publik belum berjalan optimal dan mempengaruhi kepuasan masyarakat terhadap layanan yang diberikan.

\section{DAFTAR PUSTAKA}

Bungin, B. H. (2013). Metodologi Penelitian Sosial dan Ekonomi. Jakarta: Kencana Prenada Media Grup.

Dwiyanto, A. (2014). Mewujudkan Good Governance Melalui Pelayanan Publik. Yogyakarta: Gajah Mada University Press.

Dye, T. R. (2013). Understanding Public Policy. United States: Pearson Education, Inc.

Edward III, G. C. (1980). Implementing Public Policy. Texas A\&M University: Congressional Quarterly Press.

El Anshori, Y. T., Enceng, \& Harta, R. (2017, Januari 01). One-Stop Service At Municipal Level: A Business Reform In Indonesia. Journal of Indonesian Public Administration and Governance Studies (JIPAGS), 01, 76-87.

Efendi, E. (2018),. Upaya Peningkatan Pelayanan Publik melalui Mal Pelayanan Publik, Tesis, Fakultas Hukum Universitas Indonesia, Jakarta.
Grindle, M. S. (1980). Politics and Policy Implementation in the Third World. United Kingdom: Princeton University Press.

Indrawan, R., \& Yaniati, P. (2016). Metode Penelitian Kuantitatif, Kualitatif dan Campuran untuk Manajemen, Pembangunan dan Pendidikan. Bandung: Refika Aditama.

Moleong, L. J. (2010). Metodologi Penelitian Kualitatif. Bandung: Remaja Rosdikarya.

Prasojo, E., Maksum, I. R., Epakartika, \& Kurniawan, T. (2008). Deregulasi \& Debirokratisasi Perizinan di Indonesia. Depok: Departemen Ilmu Administrasi FISIP UI.

Primadoni, (2019), Sidak Mal Pelayanan Publik di Padang, Ombudsman : Rapor Layanan Masih Merah. Diunduh di https://www.ombudsman.go.id/perwakilan Lnews/r/pwk--sidak-mal-pelayanan-publikdi-padang-ombudsman-rapor-layananmasih-merah

Van Meter, D. S., \& Van Horn, C. E. (1975). The Policy Implementation Process: A Conceptual Framework. 447.

Undang-Undang Nomor 25 Tahun 2009 Tentang pelayanan publik

Undang-undang Nomor 23 Tahun 2014 Tentang Pemerintahan Daerah

Peraturan Presiden Nomor 91 Tahun 2017 Tentang Percepatan Pelaksanaan Berusaha

Peraturan Presiden Nomor 97 Tahun 2017 Tentang Penyelenggaraan Pelayanan Terpadu Satu Pintu Peraturan Menteri Pendayagunaan Aparatur Negara dan Reformasi Birokrasi Nomor 23 Tahun $2017 \quad$ Tentang Penyelenggaraan Mal Pelayanan Publik

Peraturan Menteri Dalam Negeri Nomor 138 Tahun 2017 Tentang Penyelenggaraan Pelayanan Terpadu Satu Pintu

Peraturan Gubernur Provinsi DKI Jakarta Nomor 142 Tahun 2017 Tentang Mal Pelayanan Publik

Surat Keputusan Gubernur Provinsi DKI Jakarta Nomor 1856 Tahun 2017 Tentang Gedung Mal Pelayanan Publik

https://megapolitan.kompas.com/read/2018/03/ 12/21230791/masih-banyak-warga-belummengetahui-cara-mengadu-di-malpelayanan-publik?page $=$ all

https://www.ombudsman.go.id/perwakilan/news $\not \mathrm{r} /$ pwk--sidak-mal-pelayanan-publik-dipadang-ombudsman-rapor-layanan-masih$\underline{\text { merah }}$ 